\title{
XLIV. Memoir on some rare fossils of Vestena Nova, in the Veronais, not yet described, which were given to the museum of natural history at Paris by M. de Gazola
}

\section{Faujas-Saint-Fond}

To cite this article: Faujas-Saint-Fond (1804) XLIV. Memoir on some rare fossils of Vestena Nova, in the Veronais, not yet described, which were given to the museum of natural history at Paris by $\mathrm{M}$. de Gazola , Philosophical Magazine, 19:75, 263-267, DOI: 10.1080/14786440408676561

To link to this article: http://dx.doi.org/10.1080/14786440408676561

曲 Published online: 18 May 2009.

Submit your article to this journal $₫$

Џ Article views: 2

Q View related articles $\sqsubset$ 
they again pour over it 100 pounds of water and 20 pounds of salt, proceerling always in the same manner as above described.

The last two kinds are not strong, but very salt; especially that of the last extraction, the colour of which is also clear. These two kinds are the commonest in China. The difference between them is as $8,4,1$.

In the year 1759 I prepared in this manner, in my lodsings at Canton, all the soy which I employed. I even brought some bottles of it to Sweden: it was succulent, oily, moderately salt, and entirely different from that usually sold in Europe : in regard to its taste it was equal to that of Japan, which is generally considered as the best.

This description is the more certain, as I al ways executed the preparation myself: I will even venture to assert, that it is that used to obtain soy of the best quality.

M. Ekeberg asserts that the soy is boiled, and that sugar, ginger, and other spiceries are added : but this is void of foundation and cannot be true, since a Chinese pound of soy does not cost more than two canderins Chinese money, which are equal to $1 \frac{1}{3}$ skilling Swedish*. This was the usual price during my residence in China, and there is no reason to believe that these ingredients were employed in the preparation of it. Besides, soy has no taste either of sugar or of spiceries; the prevailing taste is that of salt.

XLIV. Memoir on some rare Fossils of Vestena Nova, in the Veronais, not yet descriled, which were given to the Museum of Natural History at Paris by M, DE GAzo* ra. By Faujas-Saint-Fondt.

$\mathrm{T}_{\mathrm{H}}$

THE collection of fossil fish found at Vestena Nova, in the $V_{\text {eronais, }}$ with which the Museum of Natural History is enriched, must be considered as unique in its kind. To employ the same constancy and activity in research that. M. de Gazola has done, one must he animated with a noble enthusiasm for the advancement of that knowledge which relates to the theory of the globe; ane must possess the same fortune and disinterestedness to sacrifice large sums for the acquisition of cabinets, and to cause researches to be made for thirty years, in the bosom of a mountain covered with lava. It was in this manner that this natiralist

* A canderin is equal to about 3 sous $7 \frac{x}{2}$ deniers French money.

$\uparrow$ From Annales du Museum National d'Histoire Nanutlle, No. 3 
obtained the most numerous collection of this kind which an individual could procure; at present it forms one of the principal ornaments of one of the galleries of the Museum of Natural History ; M, de Gazola still proposes to enlarge it, by generously adding to it the fruit of his new researches, Being desirous on the other hand to render his discoveries more generally useful, he has caused to be engraved the different and numerous species of these ichihyolites, in 3 work, the publication of which he has entrusted to the canon Volta, of Mantua, a learned naturalist, much versed in the knowledge of fish*, There are found in the stones which contain the fossil fish of Vestena, plants of the family of the ferns, the mimosa, and other terrestrial plants, which prove, that at the period when these fish were living, in the bosom of the sea, the waters did not cover the whole surface of the glohe; and that there were parts of the earth, and perbraps even whole continents, more or less elevated, where vegetation was able to develope a part of its riches.

Does not this truth, proved not only at Vestena Nova, but at Ettingen, Pappenheim, Rochesauve, and by the argillaceous schists which cover the coal mines, clearly show, that, since plants and quadrupeds then existed, as is attested by several instances, there must at the same time have been birds? I know that the facility with which birds can fly, may often rescut them from the danger of perishing in the water, and that those which are aquatic are still in less dread of that element; Ornitholites, therefore, have hitherto been very rare, some naturalists even have denied their existence.

That in the cabinet of Darcet, a figure of which has been given in the Journal de Physique, alnng with a memoir of Lamanon, has not been admitted either by Camper or Fortis: I have examined it several times, but still entertain great doubts on the subject. The same Journal for the month of Thermidor, year 8, contains an engraving of an ornitholite, or rather the impression of a bird found in the plaster-quarries of Montmartre : this fragment belongs to M. Alluin of Abbeville. As no person, however, at Paris ever saw the original, and as $M$. Alluin has given no description along with this figure, it will be prudent to wait for further details; if the drawing, however, be correct, one cannot help observing the two legs of a bird,

+ Ittiologia del Museo-Bozziano, ora nanesso a quello del conte Giovan Battsta Gazola edi altri gabinetti di fosili Veronesi, con la versione Latina. Verona dalla stamperia Guilari, 1796 , in fol. magno, with magnificent plates. 
When we read in the same number of the Journal de Physique what professor Cuvier has written on the foot of a bird, the osseous parts of which are incrusted in gypsum, from the quarries of Clignancourt near Montmartre, there is no reason to doubt that real ornitholites exist, at a great depth, in old strata of gypseous matter.

On the other hand, Blumenbach, in his Manual of $\mathrm{Na}$ tural History*, mentions bones of aquatic birds found in the marly schist of the quarries of Fttingen, and the bones of swimining birds, or anseres, discovered in the calcareous schist of Pappenheim.

I here annex a confirmation of these facts, in the figure of two feathers found in the middle of the quarries of Vestena Nova, in the same stones which contain the fish, and which I caused to be engraven of the natural size, to avoid details in regard to measures. (See Plate VI.)

That represented fig: 1 , is in perfect preservation, and as it were amalgamated with thestone: what is most remarkable is, that it is of a very black colour; it is extended and flat, and except some barbs which cross each other, the rest are arranged in the most regular manner. It cannot be confounded with certain fuci, which have some apparent rescmblance to feathers, because the barbs of the latter are furnished with other barbs. Professors Jussieu, Lamarck, Des Fontaines, and Thouin, who have examined it with attention, consider it as a real feather.

But if, notwithstanding the discussion of philosophers who are accustomed to acute observation, any doubts should be entertained of the identity of this fossil with a feather, a second feather found in the same quarry will serve to $f x$ in an irrevocable manner the opinions of philosophers on this subject. The latter, of which we have a counter-part, is represented of the natural size, fig. 2 , and 3. The stone broke so fortunately, that, like those containing the fish, it opened in the middle, in the part even containing the feather, which left its impression, while the body of the feather was found on the other; one might even say, that the feather as it were is divided in the middle.

This feather is smaller than the other, but in a preservation equally perfect; all the barbs on the left side, fig. 2 , are in their natural position; those on the right side are divided into small bunches. From the middle almost to the extremity it is a little arched, and its colour, instead of being black, is grayish.

$$
\text { * P. 408, of the } x \text { th vol. French Translation. }
$$




$$
i^{1}
$$


This feather was discovered in 1777 , and came into the possession of $\mathrm{I}$. I. Dionisi, canon of the cathedral of Verona, who is fond of the study of natural history. It was considered as a very rare object, for it was the first feather ever found in the quarries of Vestena Nova.

In regard to the first feather that is to say, the one represented fig, 1, it was sold, about ten years ago, to count Ignatius Ronconi, of Florence, then resident at Verona, by the workmen, who had taken it from. that portion of the quarry of which M. de Gazola is proprietor. These workmen, tempted by the price which $\mathbf{M}$. Ronconi, who was then forming a collection, set on this rare article, privately betrayed the confidence of the person who employed them as day-labourers. M. de Gazola, some time after, purchased from the heirs of M. Ronconi the feather with its double impression : there is seen on the stone of one of the counter-parts a small fish. M. de Gazola, when he gave the feather to the Museum which I have caused to be engraved, reserved that part to which the fish is attached; but being pleased with the reception given to him by the professors of the Museum, he has promised to deposit the second fragment in the galleries of geology, along with that which is already in it.

I have caused to be delineated on the same plate a small crab and a marine insect, presented by $\mathbf{M}$. Gazola along with the stones which contain feathers : both of them were found in the quarrry of Vestena Nova.

The marine insect, fig. 4. seems to belong to the genus pycnogonum of Fabricius, or to a genus which must approach very near to it. It is not an asilus attached to the fish, for the asili have fourteen claws, and their mouth is not formed into a tube: whereas the pycnogonum has only eight claws, and its mouth is tubular: a character found in the insect of Vestena Nova, fig. 4. Rondelet has given the figure of an insect of the Mediterranean, which has a great relation to the one in question; he distinguishes it, after Aristotle, by the Greek name orotpos, in Latin, asilus, and in French, thon marin. He has given an engraving and description of it from the insect which he found adhering under the fins of a tunny fish in the Mediterranean. The figure given by Rondelet* resembles, in regard to the character

* "Having seen the animal," says Rondeler, "I have added what follows, to the description of Aristotle: Instead of mouth it has a smalk ling rube, and on both sid's of the body there are, as it were, two hands which turn towards the mouth; then follows the hollow part of the 
sacter of the mouth, the insect of Vestena Nova, which differs from it only in the form and size of the bady, but which, like the fishes of that quarry, belongs in all probability to an exotic insect; I have, however, published a very accurate figure of it. The zoölogists will be enabled to compare it with marine insects of the same genus, which we may receive in the course of time from the Indian seas or from New Holland.

Fig. 5. represents a fossil crustaceous animal of the same place, in good preservation: it resembles the crustacea known under the name of shrimps, which belong to the genus Palcemon and Crangon of Fabricius; Cancer (artacus) squilla, Herbst, Plate XXVII, fig. 1. Cancer (artacus) crangon, of the same, Plate XXIX, fig. 3 and 4. But the Cancer squilla being much smaller than the fossil, it would be more proper to refer it to the crangon, which is the opinion of M. Latreille; whom I consulted. However, notwithstanding the respect due to the opinion of a naturalist. well versed in the knowledge of crustaceous animals, 1 should rather be inclined to consider the fossil crab in question, as nearer to the Cancer pedunculatus of Herbst, of which a representation has been given by that naturalist, in his $43 \mathrm{~d}$ coloured plate, fig. 5 . But as the latter, which is exotic, is rare, and not in the collection of the Museum, we can refer it only to the figure; it is therefore prudent to suspend our opinion till more favourable circumstances enable us to examine the insect in its natural state.

I might publish in the annals of the Museum a description of some other objects of Vestena Nova, confining myself to those which do not belong to the beautiful series of fish of the same place, destined to form the Ichthyology of the Veronais, undertaken by the canon Volta; I should even have considered it as a merit to glean in a field which belongs to him, and which he knows how to cultivate witb so much benefit to natural history, had not M. Gazola assured me, that M. Volta's work will be exclusively consecrated to a description of the fossil fish of that mountain.

body, with indentations the end of which there are six feet; the two which are short at the end of the hollow part of the body are the largest and the longest; the two following a little less, and the other two whith are more on the side, are the smallest of all. Rondelet Hist. des Porssons, $155^{8}$, folio. p. 78 . 